\title{
A comparison of the anatomical structure of the pancreas in experimental animals
}

\author{
Minoru Tsuchitani1* ${ }^{*}$ Junko Sato ${ }^{1}$, and Hiroko Kokoshima ${ }^{1}$ \\ ${ }^{1}$ Pathology Department, Nonclinical Research Center, LSI Medience Corporation, 14-1 Sunayama, Kamisu, Ibaraki 314-0255, Japan
}

\begin{abstract}
As basic knowledge for evaluation of pancreatic toxicity, anatomical structures were compared among experimental animal species, including rats, dogs, monkeys, and minipigs. In terms of gross anatomy, the pancreases of dogs, monkeys, and minipigs are compact and similar to that of humans. The rat pancreas is relatively compact at the splenic segment, but the duodenal segment is dispersed within the mesentery. In terms of histology, the islet of each animal is characterized by a topographic distribution pattern of $\alpha$-versus $\beta$-cells. $\beta$-cells occupy the large central part of the rat islet, and $\alpha$-cells are located in the periphery and occasionally exhibit cuffing. In dog islets, $\beta$-cells are distributed in all parts and $\alpha$-cells are scattered in the center or periphery of the islet (at body and left lobe); whereas $\beta$-cells occupy all parts of the islet and no $\alpha$-cells are present in the islet (at right lobe). Monkey islets show two distinct patterns, that is, $\alpha$-cell-rich or $\beta$-cell-rich islets, and the former represent peripheral $\beta$-cells forming an irregular ring. Minipig islets show an irregular outline, and both $\alpha$ - and $\beta$-cells are present in all parts of the islet, intermingling with each other. According to morphometry, the endocrine tissue accounts for $<2 \%$ of the pancreas roughly in rats and minipigs, and that of monkeys accounts for $>7 \%$ of the pancreas (at tail). The endocrine tissue proportion tends to increase as the position changes from right to left in the pancreas in each species. (DOI: 10.1293/tox.2016-0016; J Toxicol Pathol 2016; 29: 147-154)
\end{abstract}

Key words: pancreas, $\beta$-cell, $\alpha$-cell, endocrine-exocrine interface, peri-islet, extra-insular endocrine cell

\section{Introduction}

The pancreas is composed of exocrine digestive gland and endocrine cell islets, the latter being scattered throughout the former in mammalian species ${ }^{1-3}$. Exocrine injury can be induced by various agents, and endocrine injury can also be induced by certain chemicals ${ }^{4-9}$. Furthermore, exocrine injury may involve endocrine tissue ${ }^{10}, 11$. Recently, the endocrine-exocrine interface has been proposed as another target of injury with regard to pancreatic toxicity, and it is adaptable to a certain type of pancreatic lesions, peri-islet hemorrhage, and/or fibrosis, as has been previously report$\mathrm{ed}^{12-15}$. To understand pancreatic toxicity, it is important to understand the anatomical histology related to the correlation between exocrine and endocrine tissues. There is species-specific variation in the macroscopic structure and histological appearance of the pancreas; in particular, the distribution and composition of each endocrine cell in the islets varies among experimental animals ${ }^{1,4,8,10,16-18}$. Rats

Received: 18 February 2016, Accepted: 10 March 2016

Published online in J-STAGE: 1 April 2016

*Corresponding author: M Tsuchitani

(e-mail: Tsuchitani.Minoru@mp.medience.co.jp)

(C)2016 The Japanese Society of Toxicologic Pathology

This is an open-access article distributed under the terms of the Creative Commons Attribution Non-Commercial No Derivatives (by-ncnd) License $<$ http://creativecommons.org/licenses/by-nc-nd/4.0/> . and mice and dogs and monkeys have been used in toxicity studies as rodents and non-rodents, respectively, in the process of developing new pharmaceutical products. Minipigs have been utilized as experimental animals in recent years ${ }^{19,20}$. The aim of this article was to describe the comparative gross and microscopic structures of the pancreas in rats, dogs, monkeys, and minipigs and to distinguish the distribution patterns of endocrine cells within the islet of Langerhans.

\section{Development of the Exocrine and Endocrine Pancreas}

The pancreas develops from the endoderm at the caudal end of the foregut growing into the duodenum. The dorsal and ventral pancreatic anlagen appear as separate evaginations of the foregut, and with cell division, each anlage forms a pancreatic duct to the acinar lobule structure independently ${ }^{2,4,21}$. The dorsal pancreas forms part of the head, body, and tail, and the ventral pancreas forms part of the head; these growing glands merge ${ }^{2,4,21}$. The endocrine pancreas develops at the same time as the exocrine pancreas, and endocrine cells appear to be derived from the same pool of epithelial cells forming the exocrine pancreas ${ }^{2,21}$. The precursor cells may be developmentally plastic; that is, they may differentiate into either endocrine or exocrine cells $^{21}$. Endocrine cells are first observed along the base of the developing acinus ${ }^{2}$. Repetition of modified cell division 

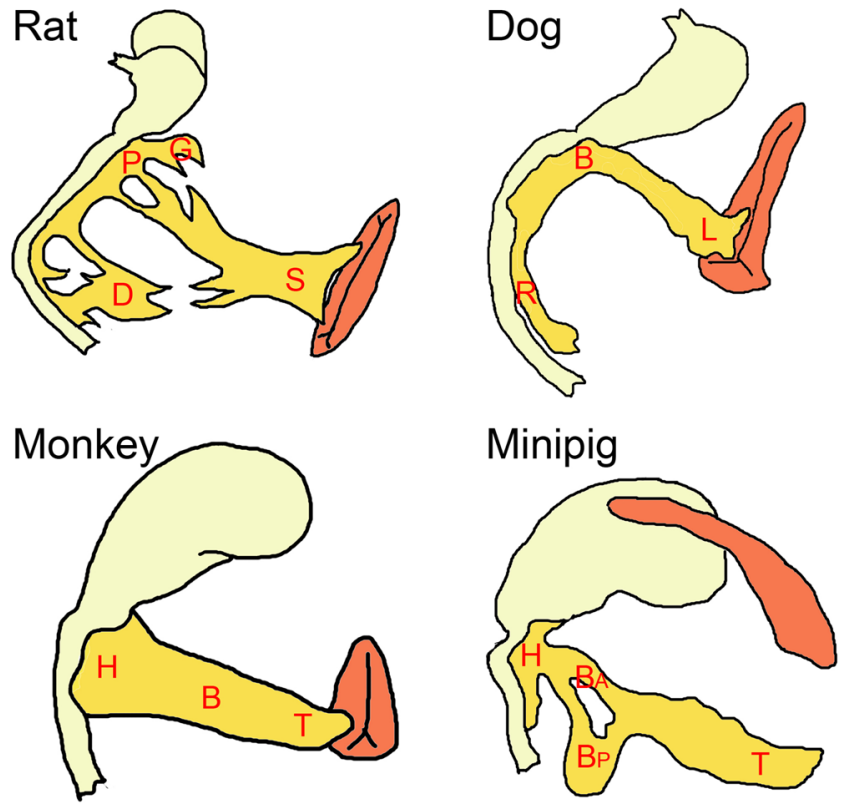

Fig. 1. The pancreas of the rat, dog, monkey, and minipig are illustrated with positional relation to the spleen and gut. The names of the lobes (portions) are as follows: $\mathrm{D}$, duodenal segment; P, parabiliary segment; G, gastric segment; S, splenic segment; $\mathrm{R}$, right lobe; $\mathrm{B}$, body; $\mathrm{B}_{\mathrm{A}}$, anterior portion of body; $B_{P}$, posterior portion of body; $L$, left lobe; $H$, head; $T$, tail.

such that daughter cells escape linkage to the neighboring epithelial cells leads to accumulation of endocrine cells free of the acinar-tubular structure ${ }^{21}$.

\section{Gross Anatomy of the Pancreas in Experimental Animals}

The human pancreas is a compact organ protected from severe trauma by lying close to the posterior abdominal wall in the upper abdomen ${ }^{3}$. The monkey pancreas appears similar to that of humans ${ }^{22}$. Macroscopic appearances of the pancreas in experimental animals can be divided into two basic patterns. The first is a diffusely distributed mesenteric type found in rabbits, and the second is a more compact type found in hamsters, dogs, and monkeys that is similar to that of humans ${ }^{10,23}$. The rat and mouse pancreas is classified as an intermediate because the splenic portion is relatively compact, but the duodenal portion is dispersed within the mesentery ${ }^{23}$. The minipig pancreas is compact. The lobation and configuration pattern of the pancreas in each experimental animal is illustrated in Fig. 1, and photographs of the macroscopic features of a removed pancreas are shown in Fig. 2.

\section{Rats}

The pancreas is divided into four parts, the gastric, splenic, parabiliary, and duodenal segments ${ }^{24}$ (Figs. 1 and 2). Recent textbooks and papers have begun to use somewhat different terms for lobation patterns, such as (1) duodenal,
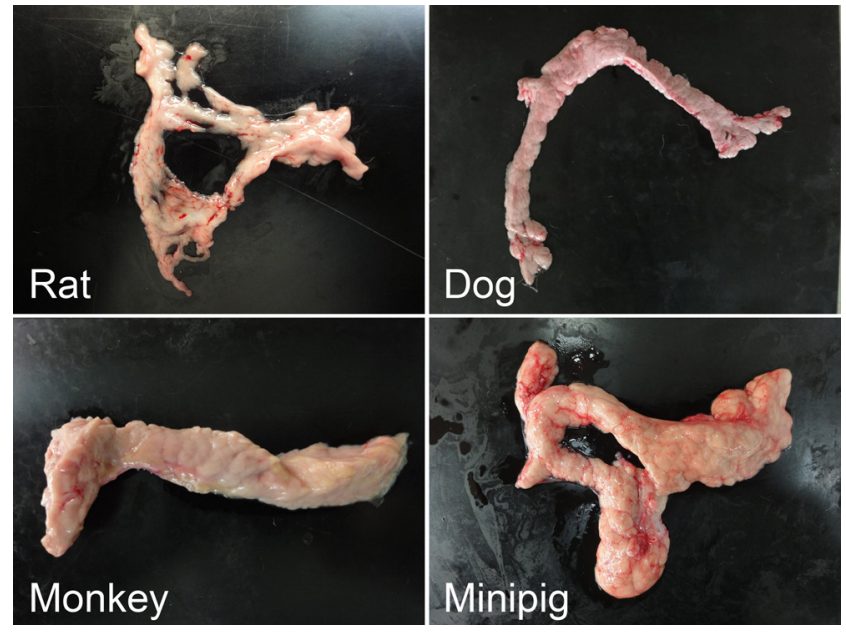

Fig. 2. Macroscopic features of the pancreas in the rat, dog, monkey, and minipig.

gastric, and splenic lobes ${ }^{4}$, (2) right lobe, body, and left lobe ${ }^{8}$, (3) gastric lobe, duodenal head, and tail ${ }^{23}$, and (4) head, body, and tail ${ }^{12,25}$. The gastric lobe in rodents has no counterpart in the other larger species ${ }^{25}$. Based on anatomical descriptions of the human pancreas, the head (parabiliary and duodenal segments) is located on the duodenal side, and the body (gastric and splenic segments) extends from the head to the stomach and spleen ${ }^{24}$. The tail (terminal part of the splenic segment) ends near the hilum of the spleen ${ }^{24}$. As mentioned above, the splenic segment is a somewhat thicker solid gland, whereas the duodenal segment is dispersed within the mesentery ${ }^{23}$. The caudal part of the duodenal segment and the dorsal part of the splenic segment are joined together and extend to near the colon.

Dogs

The pancreas is located in the dorsal part of both the epigastric and mesogastric abdominal segments, caudal to the liver, and divided into three parts, the right lobe, body, and left lobe ${ }^{26}$ (Figs. 1 and 2). A thin, slender right lobe and a shorter, thicker, and wider left lobe are united at the body (pancreatic angle), which lies caudomedial to the pylorus ${ }^{26}$. The right lobe lies in the mesoduodenum extending caudally from the body along the duodenum. The left lobe extends caudosinistrally from the body to the hilum of the spleen. The pancreas, when hardened in situ, is in the form of an inverted-V shape ${ }^{26}$.

\section{Monkeys}

The pancreas is a thick, fairly solid gland extending transversely along the dorsal wall of the abdomen from the duodenum to the spleen and is divided into three parts, the head, body, and tail ${ }^{22,27}$ (Figs. 1 and 2). The head lies within the duodenal loop and is in tight surface-to-surface contact with the duodenum. The body is directed to the left from the head, though there is no distinct anatomical landmark between the lobes. The tail is directed to the left with a nar- 
rowing of the gland and ends near the hilum of the spleen.

\section{Minipigs}

The pancreas is an extensive thick gland with an irregular outline and is basically divided into three parts, the head (right lobe), the body (including the neck), and the tail (left lobe) $3,25,28,29$ (Figs. 1 and 2). The head, which is in contact with the gut from the end of pylorus to the proximal duodenum, extends to the left and connects to the body. The body separates into two (anterior and posterior) portions that encompass the portal vein and make the pancreas appear to be "ring-shaped", and the posterior portion extends caudally ventral to the right kidney ${ }^{28-30}$. The tail is located at the left of the body and extends caudosinistrally ventral to the left kidney, and it ends near the hilum of the spleen. Meanwhile, other terms for the lobation pattern, such as "splenic" lobe (corresponding to the tail and body in the human pancreas), "duodenal" lobe (corresponding to the head of the pancreas), "connecting" lobe (corresponding to the uncinate process), and "bridge" (serving as an anatomical connection between the splenic and connecting lobes), have been used in the literature $^{30}$. Moreover, a recent textbook sited two simplified lobes, the right or head (duodenal portion) and the left or tail (splenic portion) of the pancreas, in minipigs ${ }^{8}$.

\section{Histology of the Pancreas in Experimental Ani- mals}

The pancreas is composed of exocrine and endocrine tissues $^{3},{ }^{16}$. The exocrine pancreas has a basic common structure among rats, dogs, monkeys, and minipigs, being composed of two epithelial cell types, acinar and ductal epithelial cells $\mathrm{s}^{4}$. The acinar epithelial cells make up the major portion of the pancreas, and the ductal system is composed of centroacinar cells, followed by the intercalated, intralobular, interlobular, and main ducts ${ }^{4}$. The endocrine cells form islets of Langerhans, and extra-insular endocrine cells are scattered randomly as single cells or as clusters composed of two to five cells in the components of exocrine gland tissue $^{31-34}$. The extra-insular endocrine cells are topographically related to ductal cells ${ }^{31-33}$. The topographic distribution and number of islet endocrine cells differ between the lobes of the pancreas and species $8,17,18,35$. The histological features of the pancreas in rats, dogs, monkeys, and minipigs are shown in Fig. 3, with pictures of islets characteristic to each species being shown in Fig. 4. Comparative characteristics of pancreatic islets in each species of experimental animal are summarized in Table 1.

\section{Rats}

Large- and small-sized islets are mostly present in all segments of the pancreas ${ }^{35}$. The distribution of $\alpha$-versus $\beta$-cells in the islet is basically uniform in all segments of the pancreas regardless of the size of the islet. In the islet, $\beta$-cells occupy the large central part, and $\alpha$-cells are located in the periphery and occasionally exhibit cuffing $8,17,18,35$. A small number of the $\delta$-cells are scattered in the periph- ery $^{8,35}$. Extra-insular endocrine cells are rare.

Dogs

Middle- and small-sized islets are present in the body and left lobe of the pancreas, whereas only small islets are present in the right lobe. The distribution pattern of $\alpha$ - versus $\beta$-cells in the islet is also different between the former and latter. In the body and left lobe, $\beta$-cells are distributed in all parts of the islet, and $\alpha$-cells are scattered in the center or periphery of the islet against the background of $\beta$-cells regardless of the size of the islet ${ }^{8,35}$. Fewer $\delta$-cells are scattered in the center or periphery of the islet. In the right lobe, $\beta$-cells occupy all parts of the islet, and no $\alpha$-cells are present in the islet, though a few $\delta$-cells are scattered ${ }^{8,35}$. Extrainsular endocrine cells recognized as $\alpha$-, $\beta$-, and $\delta$-cells are scattered throughout all lobes including the right one.

\section{Monkeys}

Large- to small-sized islets are present in all lobes of the pancreas. Two main distribution patterns of $\alpha$ - versus $\beta$-cells are recognized, that is, $\alpha$-cell-rich or $\beta$-cell-rich islets, in all lobes of the pancreas; although the intermediate pattern of $\alpha$ - and $\beta$-cells is comparable, it is rarely present. In the $\alpha$-cell-rich islet, $\alpha$-cells are distributed in all parts of the islet, and $\beta$-cells are scattered or accumulated in the periphery of the islet, forming an irregular ring ${ }^{35}$. In the $\beta$-cellrich islet, $\beta$-cells are distributed in all parts of the islet, and $\alpha$-cells are scattered mainly in the center but are occasionally scattered in the periphery or in all parts of the islet ${ }^{35}$. Large islets tend to be $\alpha$-cell rich and to be located in the central area of lobules. Relatively numerous $\delta$-cells are scattered in the center or periphery equally in both $\alpha$-cell-rich and $\beta$-cell-rich islets ${ }^{35}$. Extra-insular endocrine cells recognized as $\alpha-, \beta$-, and $\delta$-cells are scattered throughout all lobes.

\section{Minipigs}

Middle- and small-sized islets are present in all lobes of the pancreas. The islets frequently show an irregular outline for the following reasons: the islet cells get in the adjacent exocrine tissue and occasionally constitute a part of the acinus $^{35}$. The distribution pattern of $\alpha$ - versus $\beta$-cells in the islet is not distinctive and is basically uniform in all lobes of the pancreas regardless of the size of the islet. Both $\alpha$ - and $\beta$-cells are present in all parts, central or periphery, of the islet, intermingling with each other. In the islet, $\beta$-cells tend to make a small cluster or band, whereas, $\alpha$-cells of a large or small number tend to be scattered separately. Relatively few $\delta$-cells are scattered in all parts of the islet. Extra-insular endocrine cells recognized as $\alpha-, \beta$-, and $\delta$-cells are scattered throughout all lobes.

\section{Proportion of the Endocrine Component in the Pancreas}

According to a histology textbook, the endocrine component represents about $2 \%$ of the pancreas volume, whereas a toxicologic pathology textbook states that the endocrine 


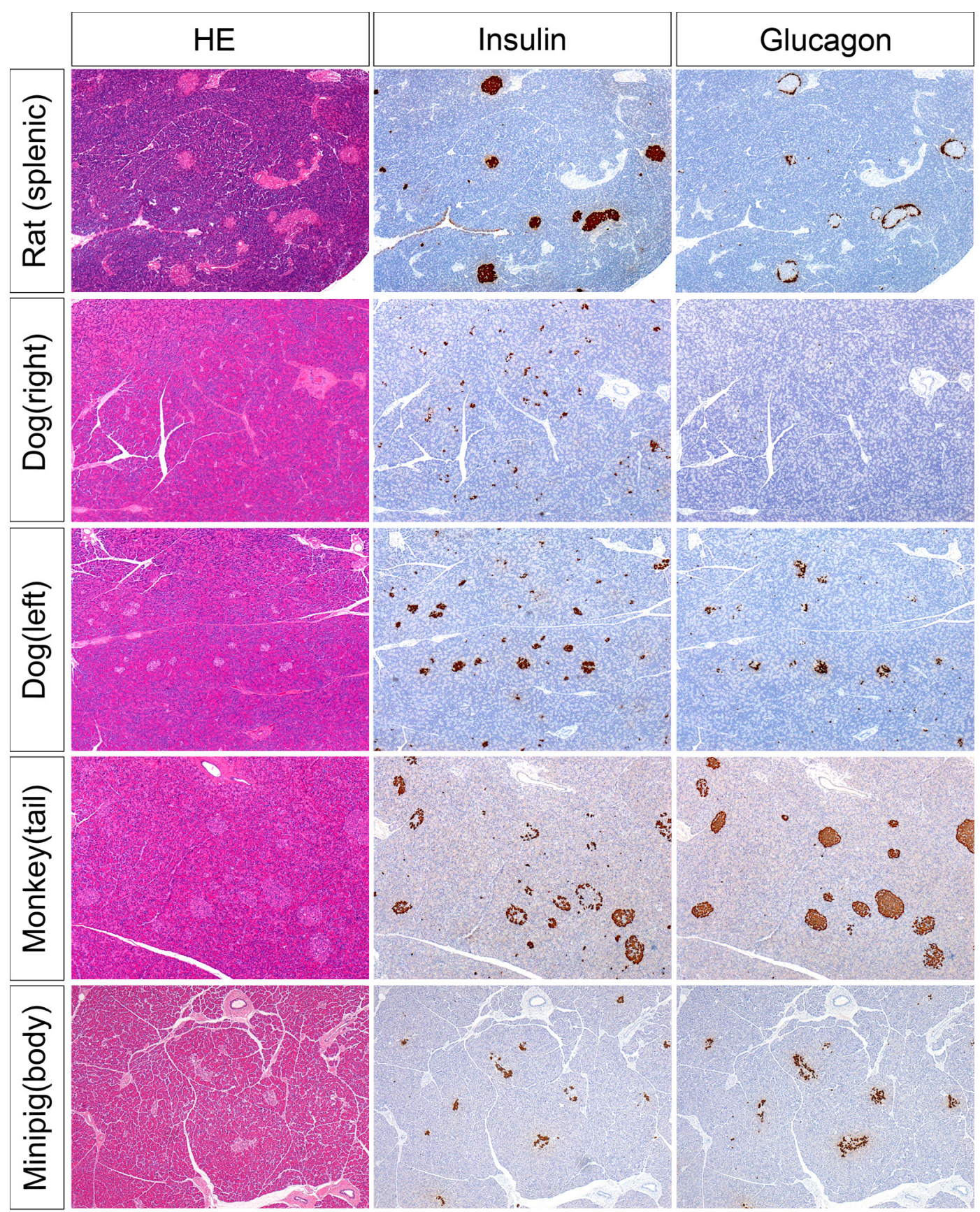

Fig. 3. Histological features of the pancreas in the rat, dog, monkey, and minipig with H\&E staining and immunohistochemistry for insulin and glucagon in serial sections. All photographs were taken using a $4 \times$ objective lens. Large islets are visible in the rat and monkey, and middle-sized islets are visible in the dog (left lobe) and minipig; only small islets are visible in the dog (right lobe).

tissue comprises $<5 \%$ of the pancreas and that the exocrine pancreatic tissue comprises the remaining $>95 \%$ of the pancreas $^{3,8}$. Though the number or volume of endocrine cells per pancreas varies between different stages of development and also changes due to age-related or disease-related alterations ${ }^{1,36,37}$, the percentage area of each morphometrically detected endocrine tissue in the pancreas of each sample animal is shown in Fig. 5. The histological preparations of a 6-week-old male rat (Crl:CD(SD)), a 21-month-old male dog (beagle), a 56-month-old male monkey (Macaca fascicu- laris), and a 21-month-old male minipig (Göttingen) were used as actual samples of appropriate age for toxicity studies. There is large interspecies and intersegment variability in the proportion of endocrine tissue. Endocrine tissue accounted for roughly $<2 \%$ of the pancreas in the rat and minipig, regardless of intersegment variability. The endocrine component of the monkey accounted for $>7 \%$ of the pancreas (tail). In the dog, monkey, and minipig, the endocrine tissue proportion increased with the change in the position from right (head) to left (tail). In the rat, the endocrine tis- 


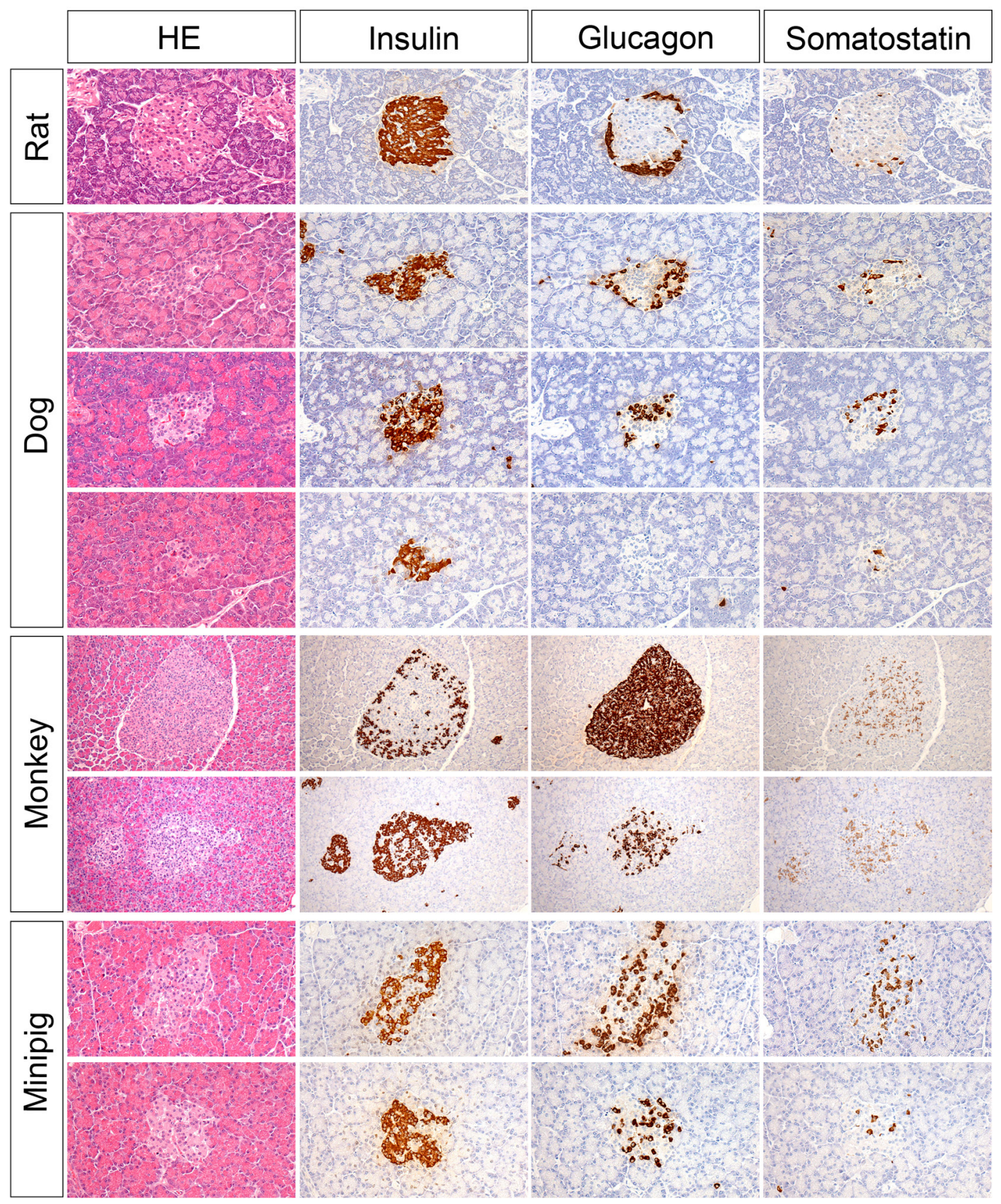

Fig. 4. Histological features of typical islets in the rat, dog, monkey, and minipig with H\&E staining and immunohistochemistry for insulin, glucagon, and somatostatin in serial sections. The photographs of the rat, dog, and minipig were taken using a $20 \times$ objective lens, and those of monkey were taken using a $10 \times$ objective lens. The photographs in the second and third rows show peripheral $\alpha$-cell and central $\alpha$-cell islets of a dog. The photographs in the fourth row show a small islet in serial sections of the right lobe of a dog, and the inset photograph in the third column shows an extra-insular $\alpha$-cell found in the same section. The photographs in the fifth and sixth rows show $\alpha$-cell-rich and $\beta$-cell-rich islets of a monkey.

sue proportion increased similarly from right (parabiliary) to left (splenic). It is notable that the $\alpha$-cell proportion in the right lobe of the dog is $0.02 \%$ of the pancreas. In the monkey and minipig, the $\alpha$-cell proportion in the tail is higher than in the other lobes as compared to $\beta$-cells. Similar tendencies for the endocrine cell proportions were indicated in the previous literature 35 .
Acknowledgments: We would like to thank Ms. Yuki Tomonari and Mr. Naoaki Yamada for their diligent support in preparation of the photographs and collection of the materials. We also thank Mr. Stephen Filiatrault and Ms. Kanae Tamatsukuri for language editing of the manuscript.

Disclosure of Potential Conflicts of Interest: The authors declare that they have no conflicts of interest. 
Table 1. Lobe Thickness, Area, Size, Extra-insular Endocrine Cell, and Distribution of $\alpha$-versus $\beta$-cells

\begin{tabular}{|c|c|c|c|c|c|c|}
\hline Rat & $\begin{array}{l}\text { Thickness of lobe }{ }^{1)} \\
\text { Islet cell area }{ }^{2)} \\
\text { Size of islets } \\
\text { Extra-insular cell } \\
\text { () }\end{array}$ & $\begin{array}{l}\text { Duodenal } \\
\text { Thin } \\
\text { S } \\
\text { L, S } \\
\text { Rare }\end{array}$ & $\begin{array}{l}\text { Parabiliary } \\
\text { Thin } \\
\text { S } \\
\text { L, S } \\
\text { Rare } \\
\end{array}$ & $\begin{array}{l}\text { Gastric } \\
\text { Thin } \\
\text { S } \\
\text { M, S } \\
\text { Rare } \\
\end{array}$ & $\begin{array}{l}\text { Splenic } \\
\text { Middle } \\
\text { S } \\
\text { L, M, S } \\
\text { Rare }\end{array}$ & Distribution of $\alpha$-versus $\beta$ - cells $^{5-}$ \\
\hline Dog & $\begin{array}{l}\text { Thickness of lobe } \\
\text { Islet cell area } \\
\text { Size of islets } \\
\text { Extra-insular cell }\end{array}$ & $\begin{array}{l}\text { Right } \\
\text { Middle } \\
\text { S } \\
\text { S } \\
\text { Scattered } \\
\end{array}$ & $\begin{array}{l}\text { Body } \\
\text { Thick } \\
\text { S } \\
\text { M, S } \\
\text { Scattered } \\
\end{array}$ & & $\begin{array}{l}\text { Left } \\
\text { Middle } \\
\text { M } \\
\text { M, S } \\
\text { Scattered }\end{array}$ & Distribution \\
\hline Monkey & $\begin{array}{l}\text { Thickness of lobe } \\
\text { Islet cell area } \\
\text { Size of islets } \\
\text { Extra-insular cell }\end{array}$ & $\begin{array}{l}\text { Head } \\
\text { Thick } \\
\text { L } \\
\text { L, M, S } \\
\text { Scattered }\end{array}$ & $\begin{array}{l}\text { Body } \\
\text { Thick } \\
\text { L } \\
\text { L, M, S } \\
\text { Scattered }\end{array}$ & & $\begin{array}{l}\text { Tail } \\
\text { Thick } \\
\text { L } \\
\text { L, M, S } \\
\text { Scattered }\end{array}$ & Distribution o \\
\hline Minipig & $\begin{array}{l}\text { Thickness of lobe } \\
\text { Islet cell area } \\
\text { Size of islets } \\
\text { Extra-insular cell }\end{array}$ & $\begin{array}{l}\text { Head } \\
\text { Thick } \\
\text { S } \\
\text { M, S } \\
\text { Scattered }\end{array}$ & $\begin{array}{l}\text { Body } \\
\text { Thick } \\
\text { S } \\
\text { M, S } \\
\text { Scattered }\end{array}$ & & $\begin{array}{l}\text { Tail } \\
\text { Thick } \\
\text { S } \\
\text { M, S } \\
\text { Scattered }\end{array}$ & Distribution of $\alpha$-versus $\beta$-cells \\
\hline
\end{tabular}

1) Thickness of the lobe detected from the cross section: thick, middle, thin. 2) Area of the islet cells roughly estimated by the total area positive for insulin, glucagon, and somatostatin in immunostained sections: L, large ( $>4 \%)$; M, middle $(<4 \%>3 \%)$; S, small (<3\%). 3) Size of the islets present mainly in the lobe: L, large; M, middle; S, small. 4) Frequency of extra-insular endocrine cells: scattered or rare. 5) Topographic distribution of $\alpha$-cells (khaki) and $\beta$-cells (green) in the islet of Langerhans.

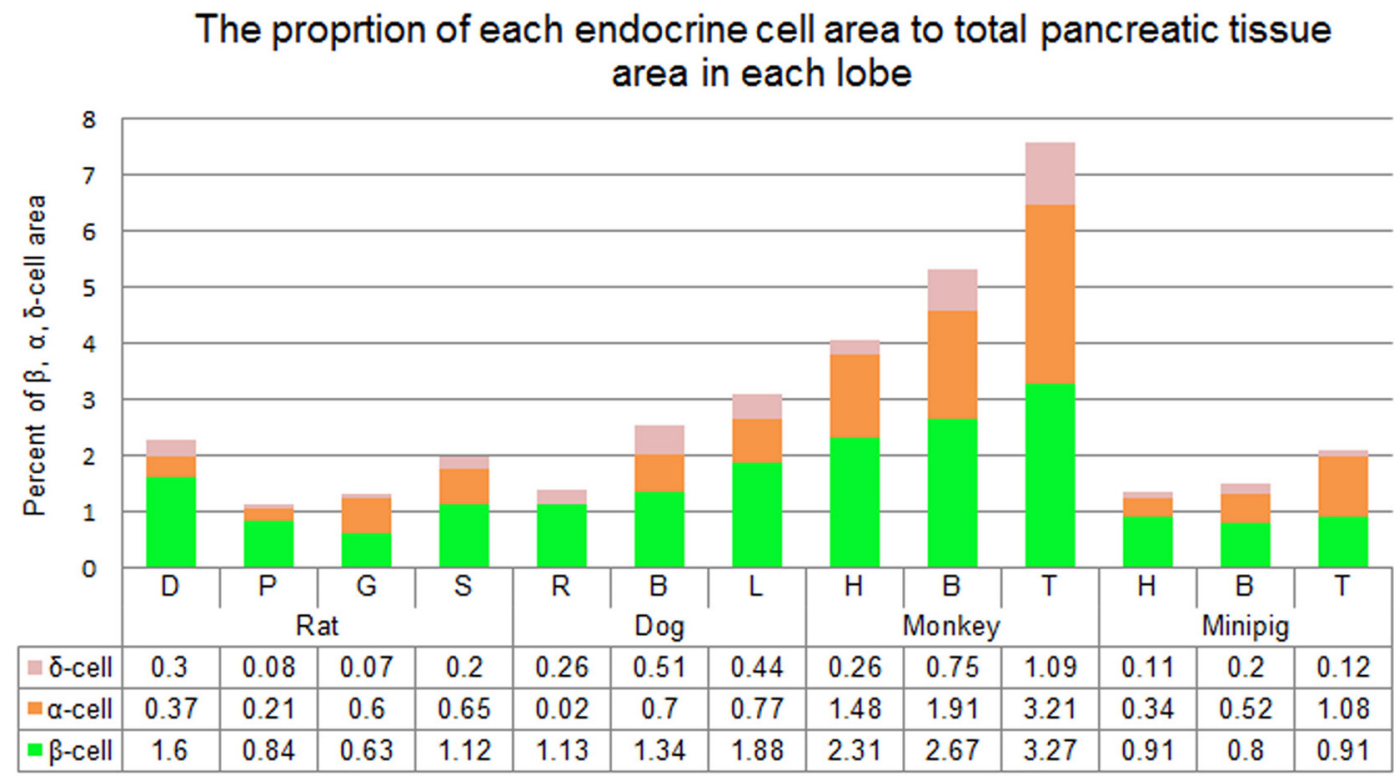

Fig. 5. Percentage areas of $\alpha$-, $\beta$-, and $\delta$-cells in the pancreas of each species. The area of each endocrine cell was measured in sections immunostained for insulin, glucagon, and somatostatin. The total area of the pancreatic tissue was measured in H\&E-stained sections cut sequentially. D, duodenal segment; P, parabiliary segment; G, gastric segment; S, splenic segment; R, right lobe; B, body; L, left lobe; H, head; T, tail.

\section{References}

1. Greaves P. Liver and Pancreas. Endocrine Pancreas. In: Histopathology of Preclinical Toxicity Studies: Interpretation and Relevance in Drug Safety Evaluation, $4^{\text {th }}$ ed. $\mathrm{P}$ Greaves (ed). Academic Press, Amsterdam. 501-510. 2012.

2. Kierszenbaum AL. Endocrine System. In: Histology and Cell Biology: An Introduction to Pathology, $2^{\text {nd }}$ ed. AL Ki- erszenbaum (ed). Mosby Elsevier, Philadelphia. 537-567. 2007.

3. Kierszenbaum AL. Digestive Glands. In: Histology and Cell Biology: An Introduction to Pathology, $2^{\text {nd }}$ ed. AL Kierszenbaum (ed). Mosby Elsevier, Philadelphia. 485-513. 2007.

4. Cattley RC, Popp JA, and Vonderfecht SL. Liver, Gallbladder, and Exocrine Pancreas. Exocrine Pancreas. In: Toxico- 
logic Pathology: Nonclinical Safety Assessment. PS Sahota, JA Popp, JF Hardisty, and C Gopinath (eds). CRC Press, Boca Raton. 345-356. 2013.

5. Kui $B$, Balla Z, Végh ET, Pallagi $P$, Venglovecz V, Iványi B, Takács T, Hegyi P, and Rakonczay Z Jr. Recent advances in the investigation of pancreatic inflammation induced by large doses of basic amino acids in rodents. Lab Invest. 94: 138-149. 2014. [Medline] [CrossRef]

6. Usborne AL, Smith AT, Engle SK, Watson DE, Sullivan $\mathrm{JM}$, and Walgren JL. Biomarkers of exocrine pancreatic injury in 2 rat acute pancreatitis models. Toxicol Pathol. 42: 195-203. 2014. [Medline] [CrossRef]

7. Foster JR. A review of animal models of nonneoplastic pancreatic diseases. Toxicol Pathol. 42: 243-259. 2014. [Medline] [CrossRef]

8. Chandra S, Hoenerhoff MJ, and Peterson R. Endocrine Glands. Pancreatic Islets. In: Toxicologic Pathology: Nonclinical Safety Assessment. PS Sahota, JA Popp, JF Hardisty, and C Gopinath (eds). CRC Press, Boca Raton. 692700. 2013.

9. Kurata Y, Katsuta O, Doi T, Kawasuso T, Hiratsuka H, Tsuchitani $\mathrm{M}$, and Umemura $\mathrm{T}$. Chronic cadmium treatment induces islet $\mathrm{B}$ cell injury in ovariectomized cynomolgus monkeys. Jpn J Vet Res. 50: 175-183. 2003. [Medline]

10. Greaves P. Liver and Pancreas. Exocrine Pancreas. In: Histopathology of Preclinical Toxicity Studies: Interpretation and Relevance in Drug Safety Evaluation, $4^{\text {th }}$ ed. P Greaves (ed). Academic Press, Amsterdam. 489-501. 2012.

11. Aghdassi AA, Mayerle J, Christochowitz S, Weiss FU, Sendler M, and Lerch MM. Animal models for investigating chronic pancreatitis. Fibrogenesis Tissue Repair. 4: 26. 2011. [Medline] [CrossRef]

12. Brenneman KA, Ramaiah SK, Rohde CM, Messing DM, O'Neil SP, Gauthier LM, Stewart ZS, Mantena SR, Shevlin KM, Leonard CG, Sokolowski SA, Lin H, Carraher DC, Jesson MI, Tomlinson L, Zhan Y, Bobrowski WF, Bailey SA, Vogel WM, Morris DL, Whiteley LO, and Davis JW 2nd. Mechanistic investigations of test article-induced pancreatic toxicity at the endocrine-exocrine interface in the rat. Toxicol Pathol. 42: 229-242. 2014. [Medline] [CrossRef]

13. Tsuchitani M, Saegusa T, Narama I, Nishikawa T, and Gonda T. A new diabetic strain of rat (WBN/Kob). Lab Anim. 19: 200-207. 1985. [Medline] [CrossRef]

14. Imaoka M, Satoh H, and Furuhama K. Age- and sex-related differences in spontaneous hemorrhage and fibrosis of the pancreatic islets in Sprague-Dawley rats. Toxicol Pathol. 35: 388-394. 2007. [Medline] [CrossRef]

15. Elmore SA, Cora MC, Gruebbel MM, Hayes SA, Hoane JS, Koizumi H, Peters R, Rosol TJ, Singh BP, and Szabo KA. Proceedings of the 2014 national toxicology program satellite symposium. Toxicol Pathol. 43: 10-40. 2015. [Medline] [CrossRef]

16. Tsutsumi M. Target-organ toxicologic pathology. Digestive system. Pancreas (exocrine). In: Ito's Toxicologic Pathology. M Takahashi and S Fukushima (eds). Maruzen Shuppan, Tokyo. 255-262. 2013; (in Japanese).

17. Furukawa F. Target-organ toxicologic pathology. Endocrine system. Pancreas (endocrine). In: Ito's Toxicologic Pathology. M Takahashi and S Fukushima (eds). Maruzen Shuppan, Tokyo. 406-411. 2013; (in Japanese).

18. Furukawa F. Pancreas (endocrine). In: Toxicologic Histo- pathology. The Japanese Society of Toxicologic Pathology (ed). IPEC, Incorporation, Tokyo.447-453. 2000; (in Japanese).

19. van der Laan JW, Brightwell J, McAnulty P, Ratky J, and Stark C. under the auspices of the Steering Group of the RETHINK Project. Regulatory acceptability of the minipig in the development of pharmaceuticals, chemicals and other products. J Pharmacol Toxicol. 62: 184-195. 2010. [CrossRef]

20. Bode G, Clausing P, Gerais F, Loegsted J, Luft J, and Nogues V. Sims J and under the auspices of the Steering Group of the RETHINK Project. The utility of the minipig as an animal model in regulatory toxicology. J Pharmacol Toxicol. 62: 196-220. 2010. [CrossRef]

21. Rutter WJ. The development of the endocrine and exocrine pancreas. In: International Academy of Pathology Monograph. The Pancreas. PJ Fitzgerald and AB Morrison (eds). Williams \& Wilkins, Baltimore. 30-38. 1980.

22. Swindler DR, and Wood CD. Abdomen. Pancreas, Duodenum, and Superior Mesenteric Artery. In: An Atlas of Primate Gross Anatomy: Baboon, Chimpanzee, and Man. DR Swindler and CD Wood (eds). University of Washington Press, Seattle. 214-215. 1973.

23. Pandiri AR. Overview of exocrine pancreatic pathobiology. Toxicol Pathol. 42: 207-216. 2014. [Medline] [CrossRef]

24. Eustis SL, Boorman GA, and Hayashi Y. Exocrine pancreas. In: Pathology of the Fischer Rat: Reference and Atlas. GA Boorman, SL Eustis, MR Elwell, CA Montgomery Jr, and WF MacKenzie (eds). Academic Press, Inc., San Diego. 95-108. 1990.

25. Haschek WM, Rousseaux CG, and Wallig MA. Pancreas. Section I Exocrine Pancreas. Normal Structure of Exocrine Pancreas. In: Fundamentals of Toxicologic Pathology, $2^{\text {nd }}$ ed. WM Haschek, CG Rousseaux, and MA Wallig (eds). Academic Press, Inc., Amsterdam. 238-240. 2010.

26. Miller ME. The Digestive System and Abdomen. Pancreas. In: Anatomy of the Dog. ME Miller (ed). W. B. Saunders Company, Philadelphia. 706-710. 1964.

27. Szebenyi ES. Atlas of Macaca Mulatta. Associated University Press, Inc., Granbury. 1969.

28. Swindle MM, Makin A, Herron AJ, Clubb FJ Jr, and Frazier KS. Swine as models in biomedical research and toxicology testing. Vet Pathol. 49: 344-356. 2012. [Medline] [CrossRef]

29. Swindle MM, Smith AC, and Smith CP. Information resources on swine in biomedical research [electronic resource]: 1990-2000, from United States Department of Agriculture, Agricultural Research Service, National Agricultural library, and Animal Welfare Information Center website: http://pubs.nal.usda.gov/information-resourcesswine-biomedical-research-2000.

30. Ferrer J, Scott WE 3rd, Weegman BP, Suszynski TM, Sutherland DER, Hering BJ, and Papas KK. Pig pancreas anatomy: implications for pancreas procurement, preservation, and islet isolation. Transplantation. 86: 1503-1510. 2008. [Medline] [CrossRef]

31. Bouwens L, and Pipeleers DG. Extra-insular beta cells associated with ductules are frequent in adult human pancreas. Diabetologia. 41: 629-633. 1998. [Medline] [CrossRef]

32. Katsuta O, Tsuchitani M, and Narama I. Abnormal proliferation of pancreatic endocrine cells in Beagle dogs. J Toxicol Pathol. 5: 67-76. 1992. [CrossRef] 
33. Son W-C, Faki K, Mowat V, and Gopinath C. Spontaneously occurring extra-islet endocrine cell proliferation in the pancreas of young Beagle dogs. Toxicol Lett. 193: 179-182. 2010. [Medline] [CrossRef]

34. Govendir M, Canfield PJ, and Church DB. Morphometric study of the $\beta$-cell volume of the canine pancreas with consideration of the axis of tissue transection. Anat Histol Embryol. 28: 351-354. 1999. [Medline] [CrossRef]

35. Wieczorek G, Pospischil A, and Perentes E. A comparative immunohistochemical study of pancreatic islets in labora- tory animals (rats, dogs, minipigs, nonhuman primates). Exp Toxicol Pathol. 50: 151-172. 1998. [Medline] [CrossRef]

36. Dillberger JE. Age-related pancreatic islet changes in Sprague-Dawley rats. Toxicol Pathol. 22: 48-55. 1994. [Medline] [CrossRef]

37. Tsuchitani M, Wako Y, Yamagishi Y, Katsuta O, Narama I, and Itakura C. Endocrine cell populations in the pancreas of diabetic WBN/Kob rats. J Vet Med Sci. 54: 429-434. 1992. [Medline] [CrossRef] 